\title{
Steven Krashen's SLA Theories and Vocabulary Teaching in College Oral English
}

\author{
Yu Wang \\ School of Humanities \\ Tianjin University of Finance and Economics \\ Tianjin, PR China \\ bonnieangel@163.com
}

\author{
Jian Yang \\ School of Humanities \\ Tianjin University of Finance and Economics \\ Tianjin, PR China \\ lyangjian@163.com
}

\begin{abstract}
This paper mainly discusses Krashen's theory of second language acquisition (SLA), especially his hypotheses, and their application into vocabulary learning and teaching during college oral English courses. By presenting the importance of oral English teaching and learning, and the present situation of vocabulary teaching at college level, a course design is proposed based on Krashen's theory; and then the method of empirical analysis and comparative study in real-world classroom setting are adopted to draw the conclusion that Krashen's theory is highly effective in instructing vocabulary teaching and learning in college oral English courses.
\end{abstract}

Keywords-SLA; Krashen; hypothesis; vocabulary

\section{INTRODUCTION}

The rapid development of globalization has witnessed the communication and nearness of people all over the world. As a necessary tool, a second language has become one of the most crucial factors when people are faced with situations like learning and job hunting. Thus issues like second language acquisition are among the increasing eye-catching fashions both in class and outside campus. As for the acquisition of a second language, that is, English for most Chinese people, a good mastery of proper amount of vocabulary has always been in the limelight. However, during college English courses, which are by no means sufficient in terms of class periods, the teaching and learning of vocabulary has functioned as a serious problem due to various reasons. As a result, college teachers of English ought to shoulder the responsibilities of probing into the issue and trying to find a solution.

\section{THE IMPORTANCE OF ORAL ENGLISH TEACHING AND LEARNING}

For most Chinese students, they have spent 6-10 years' learning in English before they enter college, but only a small part of them are with the ability of communicating in English. There even has been a saying of "dumb English" coined to describe this specific phenomenon. The teaching and learning of oral English has always been significant. From the perspective of social functions of a language, most people use their channel of listening and speaking more frequently than their channel of reading and writing. Illiterate people cannot read or write, but the illiteracy is by no means an obstacle to their communication and expression. As a matter of fact, before words were invented, oral language had played an essential role in people's daily communication. Languages are first and foremost sounds, while words are just codes and data for recording those sounds. When languages were born, people were able to exchange their ideas thoroughly with the help of intonation, rhythm and stress, none of which is with written words. The reason why children could grasp and make use of their mother tongues during an astonishing short period of time lies in the function of large amount of input of language. This input, in most cases is in the form of oral language. When it comes to the issue of acquisition of a second language, a similar answer is found. Hence, during college English courses, the teaching of oral English ought to be emphasized and put into the limelight, based on which reading and writing will be implemented.

\section{PRESENT SITUATION OF VOCABULARY TEACHING DURING COLLEGE ORAL ENGLISH COURSES}

Influenced by traditional linguistics, the teaching and learning process hasn't been set up as students-centered, resulting in low efficiency and weak interest among students. What's more, the learning of vocabulary is acquired mainly through cramming and mechanical memorizing. The natural connection between words is not established and students keep forgetting what they have learned only a short period of time afterwards. Receivers of college English teaching are those shy teenagers whose mother tongues are deeply-rooted in their minds. It must be admitted that for teenagers rather than kids, it is indeed very difficult for them to acquire a second language, because they have the rational ideas of learning actively but at the same time, they are very afraid of making mistakes, especially when they use English orally. This "awkwardness" hinders the effectiveness of teachers' class organization.

Nowadays, during college oral English courses, the common teaching methods are enhancing the time period, intensity and frequency of courses, with drills like sentence making, dialogue, repetition, discussion and debate. Although, a lot of students have built up their confidence and made some progress, they are still far from real communication in their second language. Students often struggle for proper words and phrases, and they make many mistakes in collocations. There is always something missing between students' free mastery of expression and their storage of vocabulary in their minds.

\section{STEVEN KRASHEN'S THEORY OF SECOND LANGUAGE ACQUISITION}

Since the 1970s, scholars and linguistic researchers have carried out varied studies on linguistic phenomena, linguistic rules and individual language users. The term "second 
language acquisition" was proposed accordingly. SLA refers to the learning process of any language in addition to a person's mother tongue with or without conscious instruction, or even naturally. The internalization process of a second language is always the core of subject. Different theories and modes tend to approach the subject differently. Experts of behaviorist believed that the linguistic environment is the dominant factor. As long as there is appropriate environment (input), the output from learners is guaranteed. In the behaviorist perspective, stimulus and feedback are indispensable elements in the acquisition. In the early $80 \mathrm{~s}$ of the 20th century, Steven Krashen established his systematic and comprehensive theory of SLA [1]. His theory consists of five main hypotheses: a. the Acquisition-Learning hypothesis; b. the Monitor hypothesis; c. the Natural Order hypothesis; d. the Input hypothesis; and e. the Affective Filter hypothesis [2]. According to his Monitor hypothesis of second language acquisition, he raised two conditions of SLA [3]. Firstly, in order to make learners acquire large amount of information input, the teacher has to pay attention to the filtering function of emotional factors upon input. Secondly, the input level should be higher than the existing language level of the student, and at the same time, a linguistic environment of lower affective filter should be created. Only when the above mentioned two conditions are satisfied can the input information be absorbed by students.

In Krashen's theories, language input hypothesis is the most fundamental one. He believes that acquisition is a subconscious and intuitive process of constructing language system and acquiring language abilities. This process is similar to a kid's learning process of his mother tongue. Learning is a conscious and explicit process. Krashen differentiates the differences between acquisition and learning and he believes the proficiency of a learner depends on the acquisition rather than the learning. Usually there are four problems in the teaching of vocabulary: a. learners cannot find the proper word during communication; b. learners cannot express their feelings with proper words; c. learners cannot put the words that they have learned into practice; d. learners cannot identify the words when listening to others' talking. This shows that during the teaching of vocabulary, acquisition is more important than learning. Words learned cannot be used properly in actual verbal communication. The situation is like a 7-year-old who is able to communicate with adults but cannot read or write materials with the same level of language. Contrarily, a Chinese student with an experience of English-learning for 7 years can read and write very well but is not able to communicate on a daily basis. This tells that vocabulary learning and acquisition is far from being the same thing.

\section{THE APPLICATION OF COMPULSORY INPUT INTO VOCABULARY TEACHING DURING COLLEGE COURSES}

Acquisition and learning should be combined while teaching and learning occur. Only in this way, a relatively natural learning environment could be established, and students grasp vocabulary in a relaxing surrounding. But traditional Chinese way of teaching ignores element like experiences during the process [4].

According to Krashen's Input hypothesis, language input refers to the materials that can be reached by learners in the target language, and its concept also includes various information offered by the surroundings, that is, both oral and written signs. The function and meaning of input is therefore expounded, on the basis of the internal relationship between language input and language learning. "Compulsory input" complies with Krashen's Input hypothesis, especially when the vocabulary is carefully chosen by the teacher. The materials incorporate different levels of words, phrases and collocations which are frequently used in oral English. This input is in accordance with Krashen's "comprehensible input", which is with the aim of deepening students' understanding of the vocabulary and learning to express more freely in English [5].

According to the Affective Filter hypothesis, a lot of emotional factors have impacted on the process of SLA. These emotional and affective factors have filtering functions upon language input; therefore the quantity of language input is determined. Emotional factors include: motivation, personality and emotional state. Motivation determines student's goal of learning, which plays a central role during the whole process of learning. A good personality, an extroverted character and self-confidence push students forward in their learning of a second language. Emotional state chiefly refers to anxiety and relaxation. The more anxious a person becomes, the less language input he or she gets. This is the reason for creating a relaxing and cozy environment for students which helps to relieve their anxiety and stress when they have to communicate in English [6].

\section{A. Design of Courses}

Krashen's proposal of SLA, especially the Monitor hypothesis, has explained the reason for an overwhelming phenomenon among Chinese students. Most Chinese students at college level cannot bring their thoughts to verbal expression very freely, and when the relatively small number of them does say something in English, their oral English is full of grammatical mistakes. Because just as Krashen put in his thesis, the "monitor" acts in a planning, editing and correcting function when three specific conditions are met: that is, the second language learner has sufficient time at his/her disposal, he/she focuses on form or thinks about correctness, and he/she knows the rule. Very obviously, in most cases, Chinese students don't have very solid foundation of knowledge of English grammar. Apart from this, they don't have enough time to think about the correctness and the form when they try to deliver their words. Therefore, the teacher has designed the courses.

\section{B. Subjects}

Altogether there are 30 students involved. 15 students are chosen at random as subjects and the other 15 students are for comparison and contrast. These 30 students are from the same class of the same major, with similar English level. Before and during the whole period of courses, none of the students know they are under experiment. The 15 students involved are divided into 3 groups according to different English levels with 5 members in each group.

\section{Aids}

Reading materials, test papers and MP3 audio materials are for the experiment. Altogether, there are 6 essays with roughly 500 English words in each and all the key words and phrases 
are already chosen and highlighted. These 6 essays are of different language difficulty, provided with the sequence from easy to difficult. All of them are on the topic of economy. The test is also about the topic of economy: each student is asked to say something about their understanding of economy, or give their own comments on Chinese economy, or even the global economy. During the test, the teacher asks some questions and tries to discuss with the student according to the student's speech.

\section{Steps}

- Step One: Pre-test: All the 40 students are given the same topic about economy and each of them is required to give an oral presentation within five minutes one by one, and their speeches are recorded by the MP3 for files.

- According to Krashen, the role of the monitor is - or should be - minor, being used only to correct deviations from "normal" speech and to give speech a more "polished" appearance. This means that teachers must presumably believe that students have the ability to say what they want to say, although they will probably make a lot of mistakes. In other words, teachers must have confidence in students. They should only do minor modification for students' words when this pre-test is carried out.

- Krashen also suggests that there is individual variation among language learners with regard to "monitor" use. When a task is planned, at first, the teacher must have overall information about students' level of oral English and their personality. Some of them may be shy but have very good basics of English. Some of them may need to improve their pronunciation rather than their grammar. Thus, during this pre-test, or rather the first round of individual chat, the teacher should note down the following items: pronunciation \& intonation, grammar, vocabulary, fluency, personality (extroverted or introverted), and something else that needs attention (see table I). The teacher should record this process for future use if he or she cannot write down everything so fast. Because different students have variations with regard to "monitor" use. For example, extroverts should have more constant "monitor", while introverts shouldn't be kept in "monitor" too often. This record is used as students" personal information files and should be updated regularly, so that their self-confidence is properly protected. After this survey, the second step involves dividing the class into several groups, mainly depending on their vocabulary abilities. Table I below shows roughly the way that the teacher keeps records of each student.

TABLE I. PRE-TEST FILE

\begin{tabular}{|c|c|c|c|c|c|c|}
\hline $\begin{array}{c}\text { Pronun } \\
\text { ciation }\end{array}$ & $\begin{array}{c}\text { Intona } \\
\text { tion }\end{array}$ & $\begin{array}{c}\text { Gram } \\
\text { mar }\end{array}$ & $\begin{array}{c}\text { Vocabu } \\
\text { lary }\end{array}$ & $\begin{array}{c}\text { Flue } \\
\text { ncy }\end{array}$ & $\begin{array}{c}\text { Perso } \\
\text { nality }\end{array}$ & $\begin{array}{c}\text { Ot } \\
\text { her }\end{array}$ \\
\hline & & & & & & \\
\hline
\end{tabular}

- Step Two: Experiment process: each student is provided with all the essays. The 15 subjects are required to memorize all the key words and phrases, while the other 15 students are given no specific instructions. The 15 subjects have to memorize the highlighted vocabulary in accordance with their own English level. To be specific, group one is asked to memorize the vocabulary from essay one to essay four; group two is asked to memorize the vocabulary from essay two to essay two to essay five; group three is asked to memorize the vocabulary from essay three to essay six. All the essays are for after-class assignments and the test is held one month later. The reason for assigning the essays and memorization of highlighted vocabulary as after-class activities is that when students are outside class, they tend to relax and try to stay in a comfortable environment, which is by all means helpful for their acquisition process. But the teacher does "monitor" by quoting all the vocabulary in each period of courses to arouse students' attention to this after-class assignment.

- In Krashen's Input hypothesis, he tries to explain the natural process of a learner's acquisition of a second language. $\mathrm{He}$ or she makes progress gradually. Although it is admitted that different students have different linguistic competence, all of them acquire something through "comprehensible input". For example, if a learner is at stage " $i$ ", then acquisition takes place when he/she is exposed to "Comprehensible Input" that belongs to level " $i+1$ ". As a result, when the teacher makes the plan for courses, he or she must take into consideration of different layers of materials so that he or she will make sure that every student could get something as their linguistic competence is varied. Thus this course is designed to have storage of vocabulary of several levels and each group gets their suggested copies of essays. Table II below gives an example of how the teacher offers vocabulary of three different levels to students of three different groups around the topic of "China and the world economy". Students of Group One are asked to grasp vocabulary of level 1; Group Two are required to memorize vocabulary of level 2 and students of the third group must acquire vocabulary of level 3 .

TABLE II. VOCABULARY learning sample

\begin{tabular}{|c|c|c|c|}
\hline $\begin{array}{l}\text { Group } \\
\text { number }\end{array}$ & topic & vocabulary & level \\
\hline One & \multirow{3}{*}{$\begin{array}{l}\text { China } \\
\text { and the } \\
\text { global } \\
\text { econo } \\
\text { my }\end{array}$} & $\begin{array}{l}\text { economy; economist; economic } \\
\text { balance; economic policy; bank; } \\
\text { account; check ... }\end{array}$ & 1 \\
\hline Two & & $\begin{array}{c}\text { fluctuation; depression; economic } \\
\text { stability; economic recovery ... }\end{array}$ & 2 \\
\hline Three & & $\begin{array}{l}\text { infrastructure; stagnation; initial } \\
\text { capital; frozen assets; contingency } \\
\text { fund ... }\end{array}$ & 3 \\
\hline
\end{tabular}

- Step Three: Test: After one month, all the students have the test, with the same requirement and procedures as the pre-test. Their speeches are recorded by the MP3 again.

- Step Four: Follow-up test: two months later, the same test is held again to both groups.

- Krashen's fifth hypothesis, namely Affective Filter hypothesis shows that motivation, self-confidence and 
anxiety play a facilitative, but non-causal, role in second language acquisition. If a student is highly motivated, self-confident and with a positive self-image, his or her "filter" is out of use, which leads to successful acquisition practices. On the contrary, if the student is not motivated and very anxious, he or she may have the "filter" that blocks the comprehensible input. The Affective Filter hypothesis instructs teachers to pay special attention to students' emotional factors. Thus, the procedure of each course includes several steps: first, at the beginning of each course, students must make sure that they are trying their best to adjust their psychological state to a good mood, maybe by telling jokes or reporting funny news to the whole class; and then, students are asked to review the words of different levels with or without the teacher's help; after that, a question-answer section is realized; finally comes the new words and new texts of this class. Table III below displays a designed form that is given to each student at the beginning of each course, so that everyone fills in it to have an explicit preview of the preparation for the course.

TABLE III. IN-class activity

\begin{tabular}{|c|c|c|c|c|}
\hline $\begin{array}{c}\text { Mood (good } \\
\text { or bad) }\end{array}$ & Joke & $\begin{array}{c}\text { Vocabulary } \\
\text { review }\end{array}$ & Questions & $\begin{array}{c}\text { New } \\
\text { words }\end{array}$ \\
\hline & & & & \\
\hline
\end{tabular}

\section{E. Data Collection and Analysis}

After tracking for one month, all the students are scored by the following standard: pronunciation and intonation, clear delivery, grammar, vocabulary, and fluency with one point for each aspect. The two groups are contrasted by the average score of each group (see table IV).

TABLE IV. EXPERIMENT results

\begin{tabular}{|c|c|c|}
\hline Test / Group & Subject group & Ordinary group \\
\hline Pre-test & 4.03 & 4.27 \\
\hline Test & 4.32 & 4.61 \\
\hline Follow-up test & 4.49 & 4.95 \\
\hline
\end{tabular}

The above table IV clear shows that, the comprehensible input of key vocabulary is very important in students' oral English presentation and expression. As long as the students pay enough attention to words and phrases related to a topic, they will be more likely to use them in real communication.

This experiment is carried on for 2 semesters. Every month, the teacher assigns different materials and topics to the two groups. And every month, an oral test is given on related topics.

The experiment shows that the grasp of vocabulary helps students' improvement of oral English abilities. The learning and teaching of vocabulary with contexts is an effective way of enhancing students' memory of words and phrases.

\section{CONCLUSION}

In the past, courses of college English mainly focus on students' abilities of reading comprehension and writing since the courses are to a large extent test-oriented. Such course contents of grammar, literature, linguistics and translation are all based on students' storage of vocabulary. What's more, the traditional Chinese teaching methodology highlights the function of translation in teaching, as a result of which, Chinese students' vocabulary is mostly used for reading and writing, rather than real situation communication. However, as the development of cross-cultural communication, more and more students are with the need of using English in working environment or even during routine life. The mastery of vocabulary has therefore been significant, if not essential. College English teachers should encourage students while adopting various teaching modes. Krashen's theories are highly applicable in teaching practice so as to enhance students' capability of using English comprehensively. Krashen's input hypothesis and other related theories are helpful for building approaches and methods for vocabulary teaching in class and the design of courses. Based on Krashen's SLA theory, courses are designed and experiments are done, showing that the input of vocabulary is achieved and students' oral English competence is improved.

\section{REFERENCES}

[1] S. D. Krashen, Principles and Practice in Second Language Acquisition. Oxford: Pergaman Press, 1982.

[2] S. D. Krashen, The Input Hypothesis: Issues and Implication. London: Longman, 1985.

[3] S. D. Krashen, "We Acquire Vocabulary and Spelling by Reading: Additional Evidence for the Input Hypothesis," Modern Language Journal, vol. 73 (4), pp. 440-464, 1989.

[4] B. Laufer and J. Hulstijn, "Incidental vocabulary acquisition in a second language: The construct of task-induced involvement," Applied Linguistics, vol. 22, pp.1-26, 2001.

[5] W. Wong, Input Enhancement: From Theory and Research to the Classroom. Beijing: World Book Press, 2007.

[6] G. Jordan, Theory Construction in Second Language Acquisition. Amsterdam/ Philadelphia: John Benjamins, 2004. 